\title{
Influence of Work Motivation and Discipline on Work Productivity
}

\author{
Henni Zainal \\ Universitas Indonesia Timur \\ Makassar, Indonesia
}

\begin{abstract}
This paper discusses the effect of motivation and discipline on employee productivity. Globalization has an impact on competition among the companies to get a higher profit, but they often become obstacles that employee productivity that is difficult to find a solution. This study showed that employee motivation and discipline are working together significantly influencing the productivity. This study used a quantitative research method for data analysis by surveying examining the relationship between the variables. Consequently, this research investigated the relationship between the variables, consists of the relationship between motivation and discipline as the independent variable and worked productivity dependent variable.
\end{abstract}

\section{Keywords—motivation; discipline; employee; company}

\section{INTRODUCTION}

Labor productivity is the determinant of the progress of a nation. The low quality of human resources has an impact on the low level of productivity. Contributions that attached to the employee are to provide maximum service to the community [1]. Success preserve to be achieved if a human has the motivation and discipline to improve work productivity. Productivity is one of the indicators to measure the success of the performance of individuals, teams or organizations. When productivity is high, the performance is capable of being successful. If productivity is lower or declining, it is alleged to suffer failure. In this regard, the effort to increase the productivity of employees require motivation, incentives, awards, and other motivations, considering the role of employees as a determinant of success [2]. The role of employees both in his capacity as a subordinate and leader or manager is critical to determine the success of the organization.

Besides the motivation that is supposed to affect the increase of work productivity, discipline is also expected to contribute to increase employee productivity. The discipline is associated with working time take account of the attendance level, task accomplishment, working hours, and timeliness in work accomplishment [3]. The ineffectiveness on discipline is determined by the morale in completing a job such as a lack of effort to do something creative and innovative ways. Also, the employee may also lack participation in determining the direction of the activities of the company. Moreover, this condition is expected to affect optimum employee productivity. Lack of employee productivity is reflected by lack of achievement targets. Moreover, as a company that sells services and thus has considerable competitiveness, the company is required to be able to demonstrate the productivity of the business to the consumer as a client of services.

According to Herzberg theory, motivation is a person's attitude towards to the responsibility. This attitude encourages the workforce to produce the optimal work or the incentives of the human person to perform the task well. Work motivation theoretically contains two meanings of content theory and process theory. The purpose of content theory is the sense of responsibility and ability to accept challenges. Process theory focuses on a person's cognitive process of making choices and decisions about their work. [4]

Discipline, motivation, and work would affect the performance of employees. Motivational affect the work productivity. However, motivation by stimuli indicators, as well as bonuses and allowances need a deep study on its effect on the achievement of employee productivity. Employees feel valued by the leadership and can cooperate well with fellow employees and the jobs that provided the ability and desire may also be very influential. Thus, research on motivation, work discipline and productivity of employees are still significant to be investigated further.

\section{METHOD}

This study used a quantitative approach with a survey method. This study used the three variables, in which the independent variable (dependent) consists of motivation and discipline while the dependent variable (independent) consists of work productivity. (Table I). The data collection was done by using a questionnaire with a total sample of 70 employees who were determined using proportional random sampling technique. Data were analyzed using multiple linear regression analysis [5]. 
TABLE I. VARIABLE AND INDICATORS

\begin{tabular}{|c|c|}
\hline Variable & Indicator \\
\hline Motivation & $\begin{array}{l}\text { Physical needs } \\
\text { Social interaction } \\
\text { Reward } \\
\text { Self-actualization }\end{array}$ \\
\hline Discipline & $\begin{array}{l}\text { How to work } \\
\text { Initiative } \\
\text { Obedience to the rules }\end{array}$ \\
\hline Productivity & $\begin{array}{l}\text { Quantity } \\
\text { Quality } \\
\text { Punctuality }\end{array}$ \\
\hline
\end{tabular}

\section{RESULT AND DISCUSSION}

The results showed that labour motivation in the high category. The fact that is the result of the observation of the researcher illustrates that the labour is eager in completing the main task. Leadership ability to encourage workers in achievement appears on the reward for the achievers.

Employee discipline shows that the workforce has a good morale. Work discipline appears to the obedience of rules, their initiative and the ability to get things done right. The real productivity of artistry comes from the quantity of work produced and its quality.

The research indicates that employee motivation and discipline have a positive effect on employee productivity. It also shows that if the motivation and discipline of employees increases, employee productivity will also increase. This research indicates that employee motivation and discipline of employees working together can explain about 65 percent of the variation employee productivity, which vary around 1 percent of the power of prediction models.

Thus it can be said that the constant $\beta$ has contributed about 1 percent of the forecasting model about work productivity. The above Table II is suitable for the observations made by researchers at the high productivity level of the employee affected by the motivation and discipline of a good employee. The working spirit that is the main source of the emergence of productive behaviour, where the employee works hard to achieve the targets set by the company [6].

TABLE II. WORK PRODUCTIVITY

\begin{tabular}{|c|c|c|c|c|c|}
\hline \multirow[t]{2}{*}{ Model } & \multicolumn{2}{|c|}{$\begin{array}{l}\text { Unstandardized } \\
\text { Coefficients }\end{array}$} & \multirow{2}{*}{$\begin{array}{c}\begin{array}{c}\text { Standar } \\
\text { dized } \\
\text { Coefficie } \\
\text { nts }\end{array} \\
\text { Beta }\end{array}$} & \multirow[b]{2}{*}{$\mathbf{t}$} & \multirow[b]{2}{*}{ Sig. } \\
\hline & B & $\begin{array}{c}\text { Std. } \\
\text { Error }\end{array}$ & & & \\
\hline 1 (Constant) & 42.288 & 9.108 & & 4.643 & .000 \\
\hline Motivation & .195 & .096 & .176 & 2.032 & .046 \\
\hline Discipline & .844 & 699 & 699 & 8.050 & .000 \\
\hline
\end{tabular}

\section{A. Effect of employee motivation on work productivity}

The high motivation of employee can affect employee productivity which can be proved through the inferential test. Employee motivation impacts the employee productivity [7]. It also indicates that if increased employee motivation, productivity of employees also increased. The regression equation also implies that each increase of one unit of employee motivation would be followed by the growth in employee productivity 0.19542 .288 units to a constant. Based on Table 1 above, it can be concluded that the main motivation for an employee greatly affects the work productivity. This can be done by giving the award as their motivation in achieving productivity.

\section{B. Effect on employee discipline on work productivity}

The high work discipline of employees affects employee productivity which can be examined by the inferential test. Employee discipline effects on employee productivity [8]. It also indicates that if the discipline of employees increases, the productivity of employees also increased. The regression equation also implies that each increase of one unit of work discipline of employees followed by the increase in employee productivity amounted to 0.844 units at a constant unit 42.288.

The statistical tests found out the effect of each discipline on employee productivity. The indicators such as office equipment and adherence to the rules of the office more dominant influence on variable working discipline when compared to the influence of other indicators such as timeliness, and high responsibility. Therefore, it is important for a leader of the company to further enhance the discipline of its employees to achieve high productivity.

\section{Effects of employee motivation and discipline on the employee productivity}

The results of the study indicate that the motivation and discipline of employee have a positive effect on employee productivity. It also indicates that if the motivation and discipline of employee increases, employee productivity also increase. Multiple regression equations also imply that any increase in each of the units of employee motivation and employee discipline would be followed by the increase in employee productivity 0.195 and 0.844 at 42.288 constants unit.

This study showed that the power of prediction models is given by the coefficient of determination value of 0.660 and this indicates that the power of prediction model has about 66 percent of the variation employee productivity can be explained by the model. The determination coefficient value was corrected by 0.650 . This value indicates that the motivation and discipline of an employee can explain simultaneously about 65 percent of the variation employee productivity, which vary around 1 percent of the power of prediction models. Thus, it can be said that the constant $\beta$ has contributed about 1 percent of the forecasting model about work productivity.

\section{CONCLUSION}

The research indicates that employee motivation and discipline of employees have a positive effect on employee productivity. It also indicates that if the motivation and discipline of employee increases, employee productivity also increases. Employee motivation impacts the employee productivity. It also indicates that if increased employee 
motivation, the productivity of employees also increased. Giving the award is one way of stimulating employee motivation in achieving productivity. Employee discipline effects on employee productivity. It also indicates that if the discipline of employee increases, the productivity of employee also increases. This study indicates that if the motivation and discipline of employees increases, employee productivity also increases.

\section{REFERENCES}

[1] D. D. Gremler and K. P. Gwinner, 'Customer-employee rapport in service relationships', J. Serv. Res., vol. 3, no. 1 , pp. 82-104, 2000.

[2] S. A. Haslam, C. Powell, and J. Turner, 'Social identity, self- categorization, and work motivation: rethinking the contribution of the group to positive and sustainable organisational outcomes', Appl. Psychol., vol. 49, no. 3, pp. 319-339, 2000.

[3] J. R. Katzenbach and D. K. Smith, The discipline of teams. Harvard Business Press, 1993.

[4] E. A. Maidani, 'Comparative study of Herzberg's twofactor theory of job satisfaction among public and private sectors', Public Pers. Manage., vol. 20, no. 4, pp. 441448, 1991.

[5] P. R. Hinton, I. McMurray, and C. Brownlow, SPSS explained. Routledge, 2014.

[6] R. Karasek and T. Theorell, Healthy work: stress, productivity, and the reconstruction of working life. Basic books, 1992.

[7] H.-F. Lin, 'Effects of extrinsic and intrinsic motivation on employee knowledge sharing intentions', J. Inf. Sci., vol. 33, no. 2, pp. 135-149, 2007.

[8] C. Casey, “" Come, join our family”: Discipline and integration in corporate organizational culture', Hum. relations, vol. 52, no. 1, pp. 155-178, 1999. 